\title{
Pendampingan Pengabdian Masyarakat Ukm Tempe Dan Makanan Kecil Di Aisyiyah Gabang Godean
}

\author{
Tri Maryati1*, Hasnah Rimiyatí2, dan Nila Fadilatul Jannah ${ }^{3}$ \\ 1,2,3. Program Studi Manajemen, Fakultas Ekonomi dan Bisnis, Universitas Muhammadiyah Yogyakarta, J. Brawijaya Tamantirto Kasihan \\ Bantul Yogyakarta 55183 Telp (0274)387656 \\ Email: try_maryati@umy.ac.id \\ DOI: 18196/ppm.31.143
}

\begin{abstract}
Abstrak
UKM yang didampingi adalah produksi tempe dan makanan kecil. Permasalahan yang dihadapi oleh UKM tempe adalah proses pengelupasan kulit kedelai yang masih menggunakan cara tradisional, kemasan yang masih sederhana dan belum mempunyai pembukuan kevangan. Permasalahan yang dihadapi oleh usaha makanan kecil adalah kemasan produk yang belum menarik, masih rendahnya omzet penjualan dan belum punya pembukuan keuangan. Tujuan pendampingan membantu : (1) UKM tempe untuk alih teknologi dari cara tradisioanal dengan cara yang lebih modern, (2) UKM makanan kecil untuk memperoleh PIRT, (3) UKM tempe dan makanan kecil cara melakukan pengemasan produk yang menarik, (4) UKM makanan kecil memiliki media promosi online, (5) UKM tempe dan makanan kecil memiliki administras keuangan. Metode yang akan digunakan adalah dengan memberikan penyuluhan dan pendampingan tentang desain kemasan, promosi produk, dan administrasi keuangan. Implikasi dari pendampingan adalah UKM tempe dan makanan kecil omzetnya meningkat. Hasil pendampingan :(1) UKM tempe sudah beralih teknologi menggunakan mesin, (2) UKM makanan kecil sudah memiliki PIRT, (3) UKM tempe dan makanan kecil sudah memiliki kemasan yang menarik dilengkapi dengan merek dengan nama "BAROKAH" dan logo bertuliskan MEK Aisyiyah Cabang Godean, (4) UKM makanan kecil sudah memiliki media promosi secara online yaitu melalui wa bisnis dengan nama B. Minah Snak dan Instagram dengan nama Sarminah48, dan (5) Baik UKM tempe maupun makanan kecil sudah memiliki buku administrasi keuangan.
\end{abstract}

Kata Kunci: alih teknologi, pengemasan, promosi, keuangan

\section{Pendahuluan}

Upaya untuk meningkatkan kesejahteraan anggota Aisyiyah, pimpinan Cabang Aisyiyah Godean berkomitmen untuk meningkatkan keuangan keluarga dengan berwirausaha. Program Kerja Majelis Ekonomi Pimpinan Pusat Aisyiyah tahun 2019 adalah mengembangkan, meningkatkan, dan memberdayakan ekonomi masyarakat, baik melalui pengembangan wirausaha maupun pelatihan ketrampilan dan jaringan usaha. (http://www.aisyiyah.or.id/id/page/majelis-ekonomi-danketenagakerjaan.html). Untuk menindaklanjuti program kerja ini maka Aisyiyah Cabang Godean berkomitmen untuk mengembangkan UKM tempe dan makanan kecil. Tempe adalah makanan tradisional dengan protein tinggi (Shurtleff and Aoyagi, 1979 dalam Utama, 2019). Berdasarkan data komposisi pangan Indonesia dari Kementerian Kesehatan RI, 100 gram tempe dan tahu memiliki kandungan gizi yang berbeda. Kandungan gizi dalam 100 gram tempe adalah : Energi: 150 kal, Protein: 14 gram, Lemak: 7,7 gram, Karbohidrat: 9,1 gram, Serat : 1,4 gram, Kalsium: 517 mg, Natrium: 7 mg dan Fosfor: $202 \mathrm{mg}$. (https://hellosehat.com/hidup-sehat/nutrisi/tempe-dan-tahu-menurunkan-beratbadan/). Industri kecil tempe banyak tersebar di kawasan perkotaan sampai ke pedesaan. UKM tempe di pedesaan dalam proses produksinya masih menggunakan cara manual untuk mengelupas kulit kedelai yaitu dengan cara di injak-injak sehingga hasilnya kurang higienes. UKM yang didampingi adalah UKM tempe milik Ibu Ekowati.

Makanan kecil merupakan camilan yang disukai oleh masyarakat baik sebagai teman santai juga bisa dipakai untuk oleh-oleh. UKM makanan kecil yang didampingi adalah usaha milik Ibu Sarminah yang memproduksi aneka makanan kecil. Pasar dari makanan kecil ini masih terbatas. Harapan dari Aisyiyah bahwa produk tersebut mampu menembus pasaran yang lebih luas. Untuk itu produk tersebut harus memiliki ijin PIRT, kemasan produk yang menarik dan promosi agar produk tersebut dikenal masyarakat luas. Menurut Kotler \& Keller (2013) promosi adalah bagian dan proses strategi pemasaran sebagai cara untuk berkomunikasi dengan pasar dengan menggunakan komposisi bauran promosi "promotional mix". 
Untuk tertib keuangan UKM harus memiliki administrasi pembukuan keuangan walaupun hanya sederhana. UKM tempe maupun makanan kecil belum mempunyai administrasi pembukuan keuangan. Laporan keuangan sederhana yang harus dimiliki UKM berupa buku arus kas, persediaan barang, pembelian, penjualan, biaya, utang, dan piutang : . (https://www.jurnal.id/id/blog/cara-mudahmembuat-laporan-keuangan-sederhana-bagi-ukm/).

Tujuan pengabdian masyarakat membantu : (1) UKM tempe untuk alih teknologi dari cara tradisioanal dengan cara yang lebih modern, (2) UKM makanan kecil untuk memperoleh PIRT, (3) UKM tempe dan makanan kecil memiliki kemasan produk yang menarik,(4) UKM makanan kecil memiliki media promosi secara online, (5) UKM tempe dan makanan kecil memiliki administras pembukuan keuangan.

Manfaat dari pengabdian masyarakat ini adalah : (1) dengan kemasan yang menarik akan bisa meningkatkan penjualan produk tempe dan makanan kecil , (2) dengan diperolehnya PIRT produk makanan kecil bisa diterima di toko sehingga dapat meningkatkan market share, dan (3) dengan adanya administrasi pembukuan keuangan maka akan bisa diketahui perkembangan penjualan baik untuk produk tempe maupun makanan kecil.

Metode Pelaksanaan

Metode Pelaksanaan Kegiatan.

a. UKM Tempe.

1) Memberi penyuluhan tentang pentingnya alih teknologi dari cara tradisional dengan cara modern dengan menggunakan mesin yang lebih higienis.

2) Memberi penyuluhan tentang pentingnya pengemasan yang menarik yaitu dengan perlunya kemasan untuk diberi merek dan logo.

3) Mendampingi pembuatan design merek.

4) Membuatkan logo.

5) Membuatkan form buku kas dan biaya.

b. UKM makanan kecil.

1) Aspek Produk.

Membantu mengisi form isian yang disediakan oleh Dinas Kesehatan Kabupaten Sleman dan melakukan pendampingan sampai mendapatkan PIRT.

2) Aspek Pemasaran.

a) Memberi penyuluhan tentang pentingnya packaging / pengemasan yang menarik.

b) Memberi penyuluhan tentang pentingnya melakukan promosi.

c) Melakukan pendampingan pembuatan desain promosi offline yaitu berupa papan nama.

d) Melakukan pendampingan pembuatan label dan logo.

e) Melakukan pendampingan packaging produk .

f) Membuatkan media promosi online melalui Instagram dan wa bisnis.

3. Aspek administrasi keuangan.

a) Memberikan penyuluhan tentang administrasi pembukuan keuangan.

b) Membuatkan form buku kas, biaya, persediaan bahan baku, produksi dan penjualan produk.

Hasil dan Pembahasan

Hasil yang dicapai dalam pengabdian masyarakat dibagi menjadi dua yaitu untuk UKM tempe dan UKM makanan kecil.

UKM tempe

Aspek Produk :

a. Pada tanggal 29 Mei 2020 bertempat di UKM tempe menjelaskan tentang pentingnya alih teknologi dari cara tradisional dengan cara modern dengan menggunakan mesin yang lebih higienis. Cara yang modern ini hasil tempenya tentunya lebih bersih dan sehat.

b. Pada hari Selasa tanggal 9 Juni 2020 bertempat di UKM tempe, menyerahkan mesin pengelupas kedelai dan triplek untuk mengangin-anginkan tempe yang sudah jadi.

Berikut adalah proses produksi dengan alih teknologi menggunakan mesin pengelupas kedelai : 

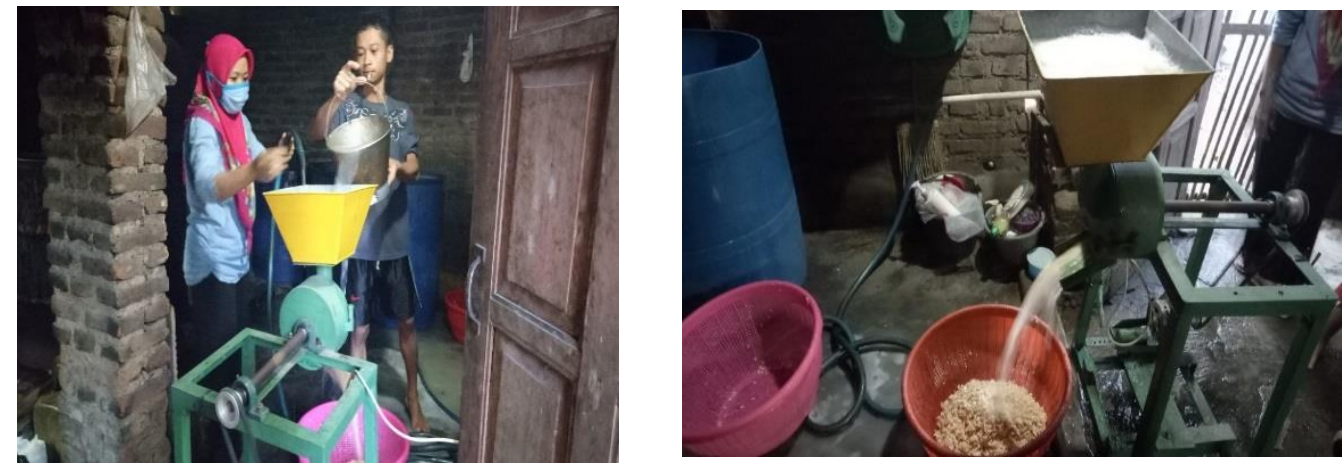

Gambar1. Proses Pengelupasan kulit kedelai dengan mesin pengelupas

Aspek Pemasaran :

a. Pada tanggal 29 Mei 2020 bertempat di UKM tempe memberikan penyuluhan tentang pentingnya pengemasan yang menarik yaitu dengan perlunya kemasan untuk diberi merek dan logo.

Pemberian merek pada suatu produk bertujuan untuk beberapa alasan, yaitu

1. Untuk identifikasi, guna mempermudah penanganan (handling) atau mencari jejak (tracing) produk dipasarkan.

2. Melindungi produk yang unik dari kemungkinan ditiru pesaing.

3. Produsen ingin menekankan mutu tertentu yang ditawaran dan untuk mempermudah konsumen menemukan produk tersebut kembali.

b. Pada tanggal 8 Juni 2020 membuatkan design kemasan, merek dan logo tempe

Berikut adalah desain kemasan dan hasil pengemasan produk tempe.
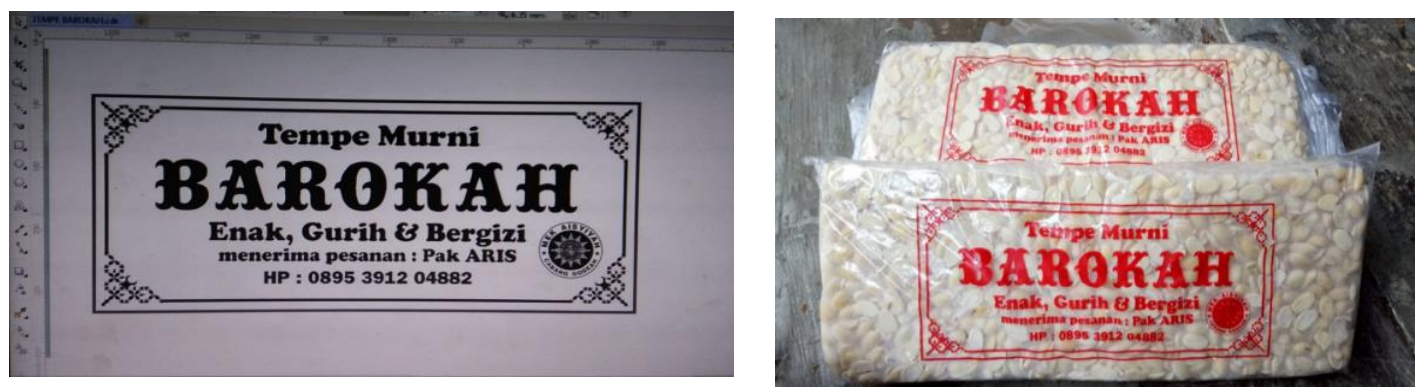

Gambar 2. Desain kemasan

Gambar 3. Kemasan produk tempe

Aspek Administrasi Keuangan.

Untuk tertib pembukuan dalam keuangan, maka pada tanggal 9 Juni 2020 di UKM tempe diberikan penyuluhan tentang pentingnya membuat pembukuan keuangan dan macam bentuk administrasi keuangan yang sederhana yaitu berupa buku kas dan buku biaya.

Hasilnya bahwa pengusaha tempe sudah bisa membuat administrasi pembukuan keuangan.
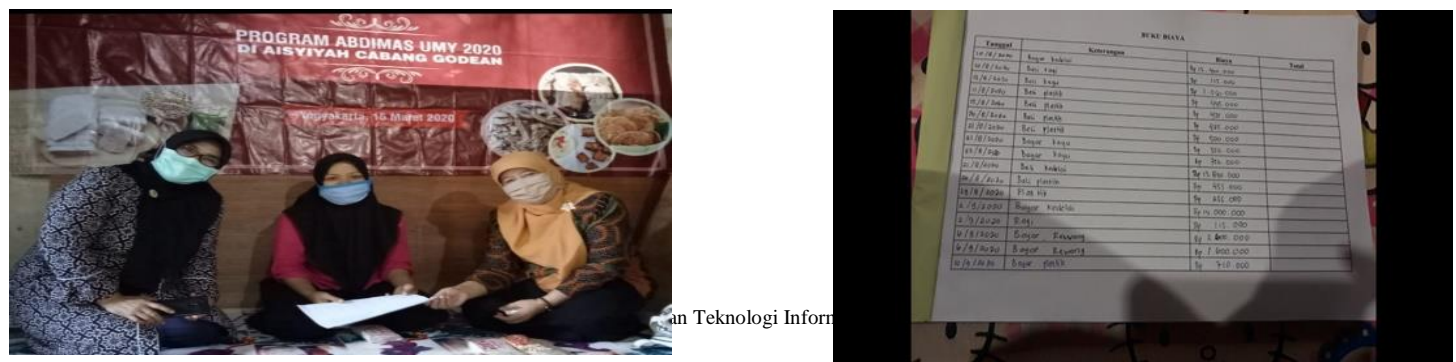


\section{UKM Produk Makanan kecil.}

Aspek Produk:

Dalam rangka untuk memperoleh sertifikat PIRT, maka pada bulan Januari 2020 dilakukan pendampingan pengisian form yang disediakan oleh Dinas Kesehatan Kabupaten Sleman dan melakukan pendampingan sampai mendapatkan PIRT.

Pada tanggal 11 Maret 2020 ajuan untuk memperoleh Nomor P-IRT untuk hasil olahan bijibijian, kacang-kacangan dan umbi dikabulkan dengan nomor 2153404012224-25, serta tepung dan hasil olahannya dengan nomor 2063404012224-25

Aspek Pemasaran :

a. Packaging atau kemasan.

Permasalahan yang dihadapi oleh mitra adalah bahwa kemasan produk yang sudah ada akan tetapi kurang menarik dan belum ada izin PIRT, sehingga pada kegiatan pengabdian masyarakat ini adalah membantu mendesain ulang kemasan, harapannya konsumen akan lebih tertarik untuk membeli produk tersebut.

Berikut adalah hasil pembuatan label dan logo aneka makanan kecil.
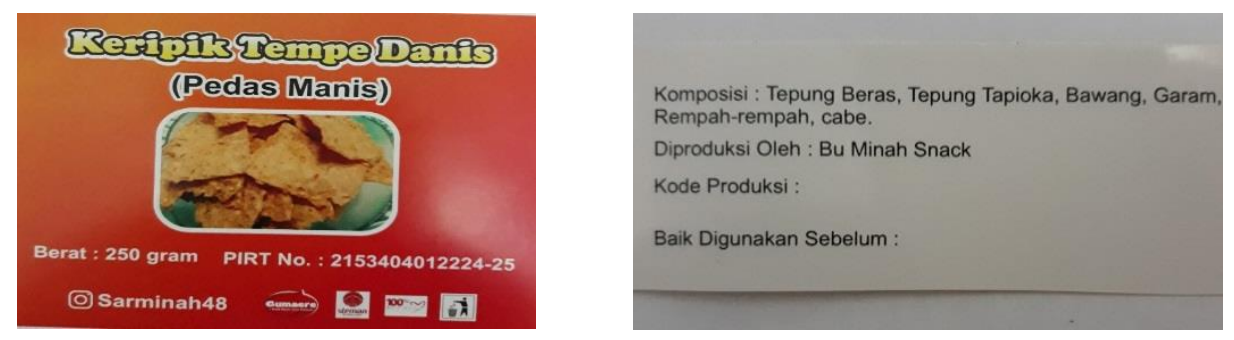

Gambar 6. Desain merek, logo dan label keripik tempe
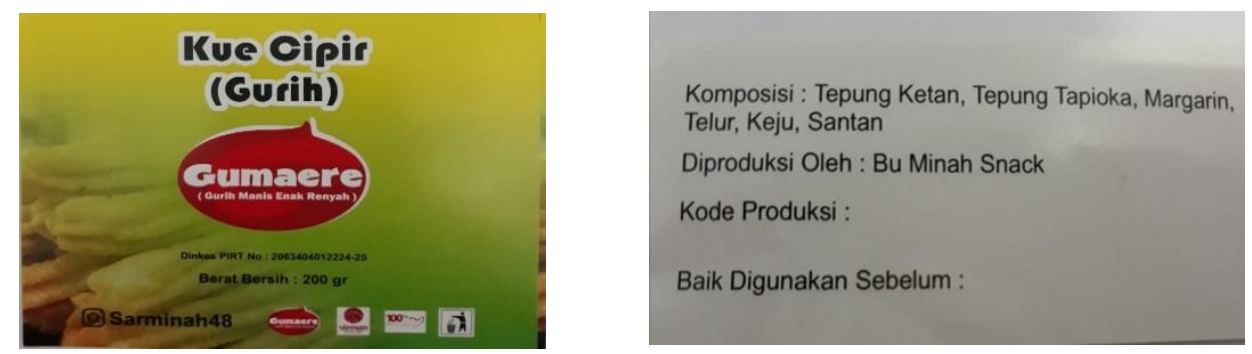

Gambar 7. Desain merek, logo dan label kue cipir gurih

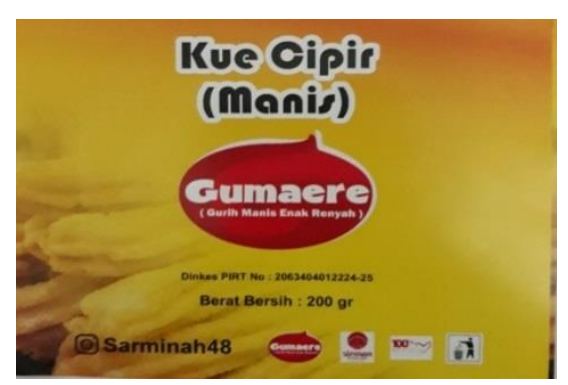

Komposisi : Tepung Ketan, Tepung Tapioka, Margarin, Telur, Keju, Santan

Diproduksi Oleh : Bu Minah Snack

Kode Produksi :

Baik Digunakan Sebelum : 
Gambar 8. Desain merek, logo dan label kue cipir manis

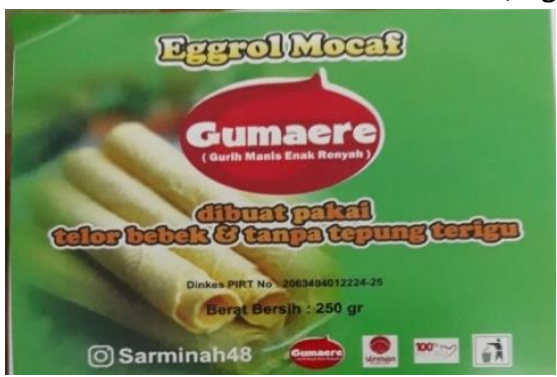

Gambar 9. Desain merek, logo dan label Eggrol Mocaf

Berikut adalah hasil pengemasan produk makanan kecil yang terdiri dari keripik tempe, kue cipir, dan eggrol.

Pengemasan Produk keripik tempe.

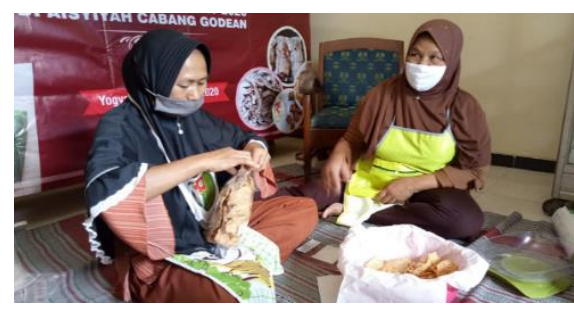

Gambar 10. Proses pengemasan keripik tempe

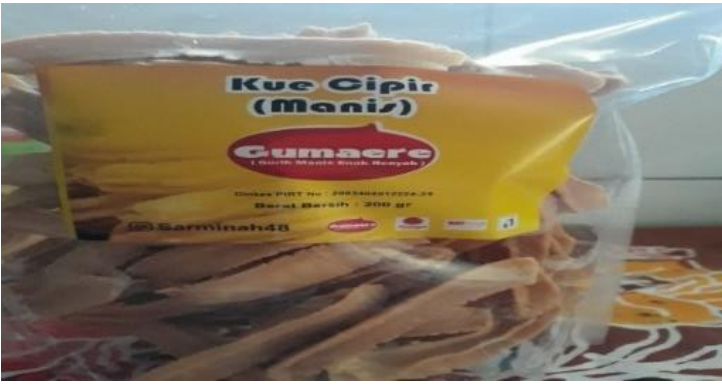

Gambar 12. Produk Kecipir yang sudah sudah dikemas

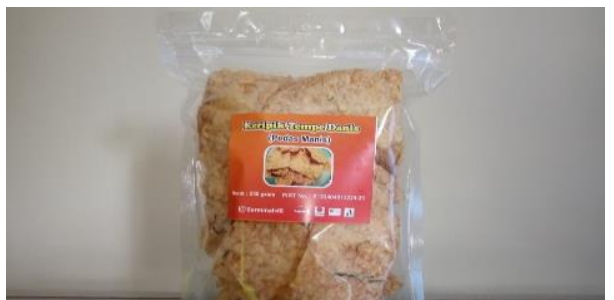

Gambar 11. Produk sudah dikemas

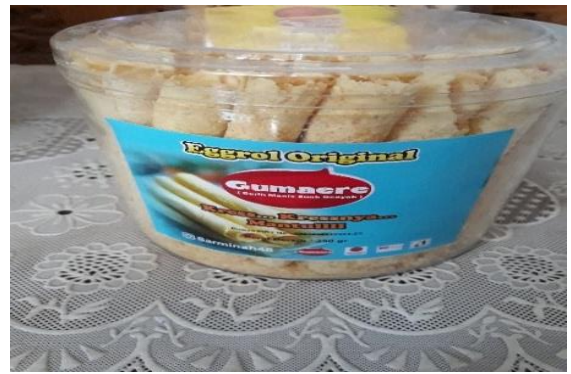

Gambar 13. Produk Eggrol yang sudah dikemas

\section{b.Promosi Penjualan.}

Promosi bisa dilakukan melalui media tradisional dan media digital. Promosi melalui media tradisional adalah via media cetak seperti koran, majalah, tabloid, dan sejenisnya, dan media elektronik seperti radio dan televisi, serta media di luar ruangan seperti iklan banner atau papan reklame atau papan billboard. Sedangkan promosi melalui media digital mencakup media internet dan sosial media atau jejaring sosial.

Berikut adalah luaran kegiatan pembuatan media promosi yang terdiri dari media offline dan online.

a. Media offline yang dikerjakan adalah membantu membuatkan papan nama, sebagai berikut : 

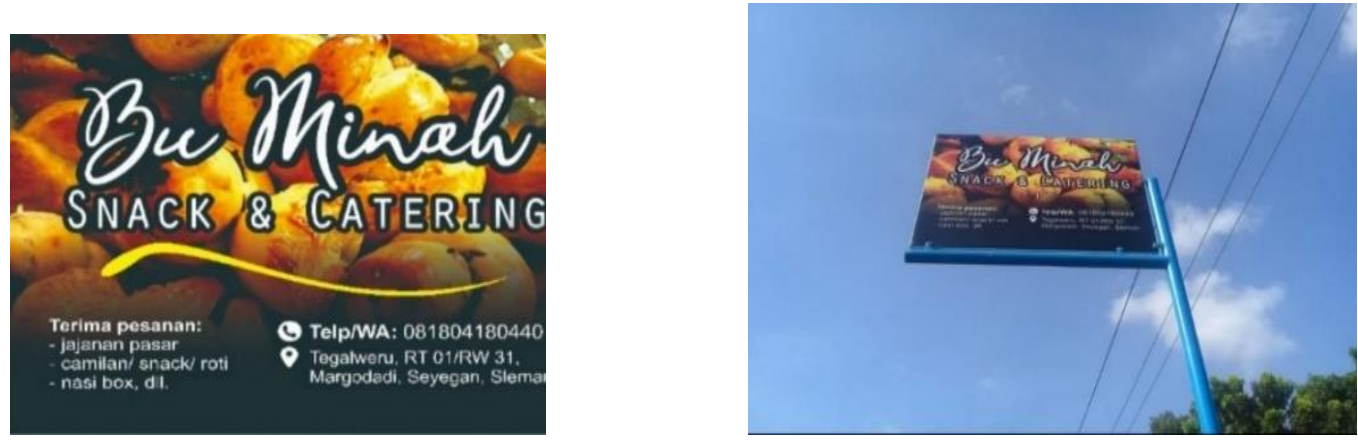

Gambar 14. Media promosi offline

b. Media promosi online yaitu melalui wa bisnis dan Instagram (IG).
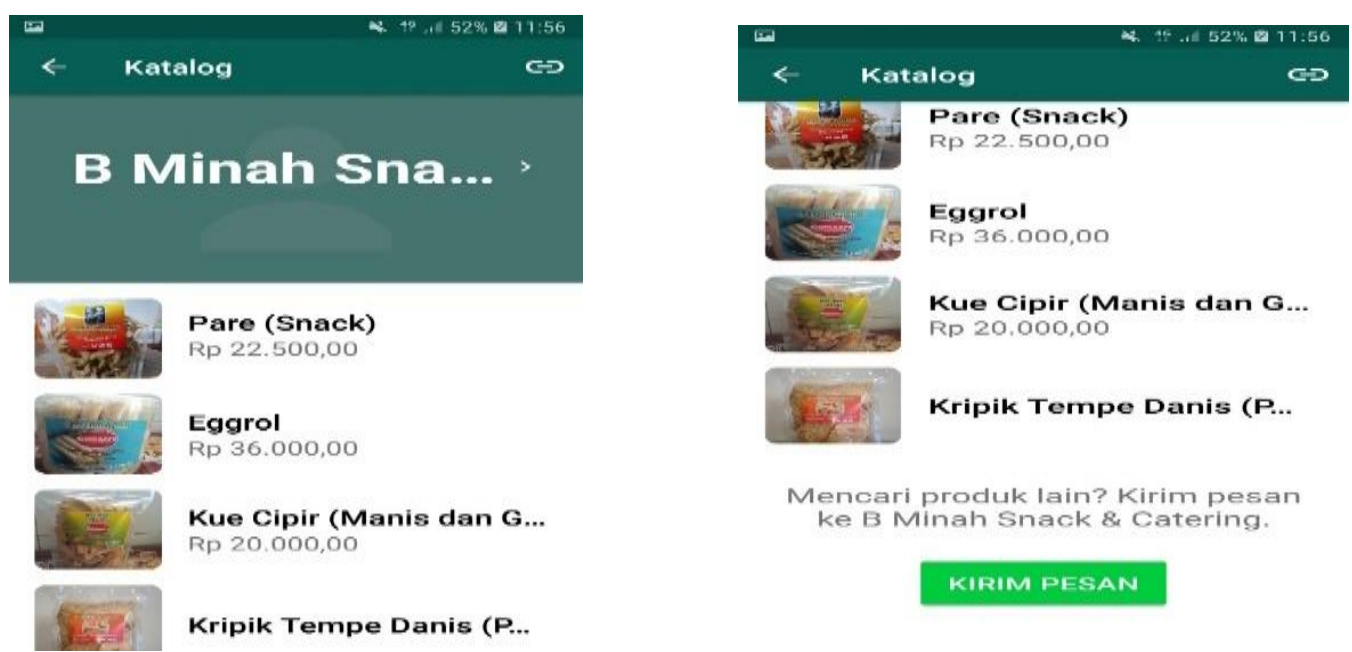

Gambar 15 Wa bisnis

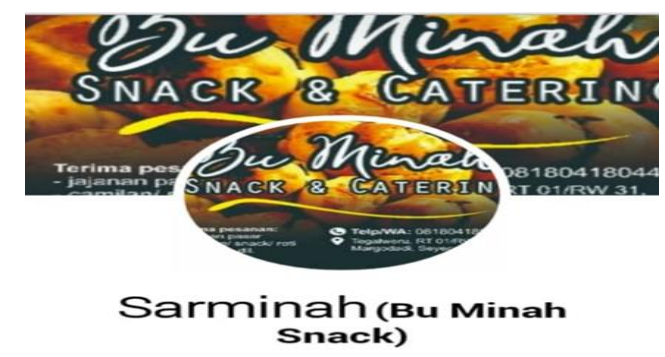

Bagikan kabar terbaru Andake

\section{a. Aspek administrasi pembukuan keuangan.}

Menurut Undang-Undang Nomor 28 Tahun 2007, pembukuan sederhana adalah suatu proses pencatatan yang dilakukan secara teratur untuk mengumpulkan data dan informasi keuangan.

Untuk administrasi pembukuan keuangan di UKM tempe dan makanan kecil dibuatkan format pembukuan sederhana meliputi : buku persediaan bahan baku, buku produksi dan penjualan, buku kas, buku biaya.

Hasil dari pendampingan penyusunan administrasi pembukuan keuangan, pemilik UKM tempe sudah mampu menyusun buku kas, buku biaya, buku persediaan bahan baku, buku produksi dan penjualan, 
Berikut contoh pembukuan keuangan yang sudah dilakukan :

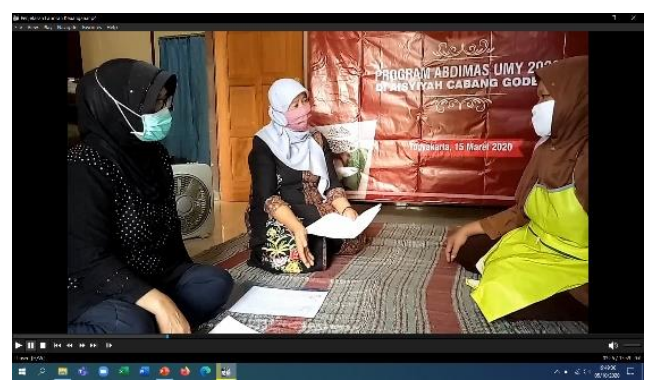

Gambar 17.Pelatihan pembukuan
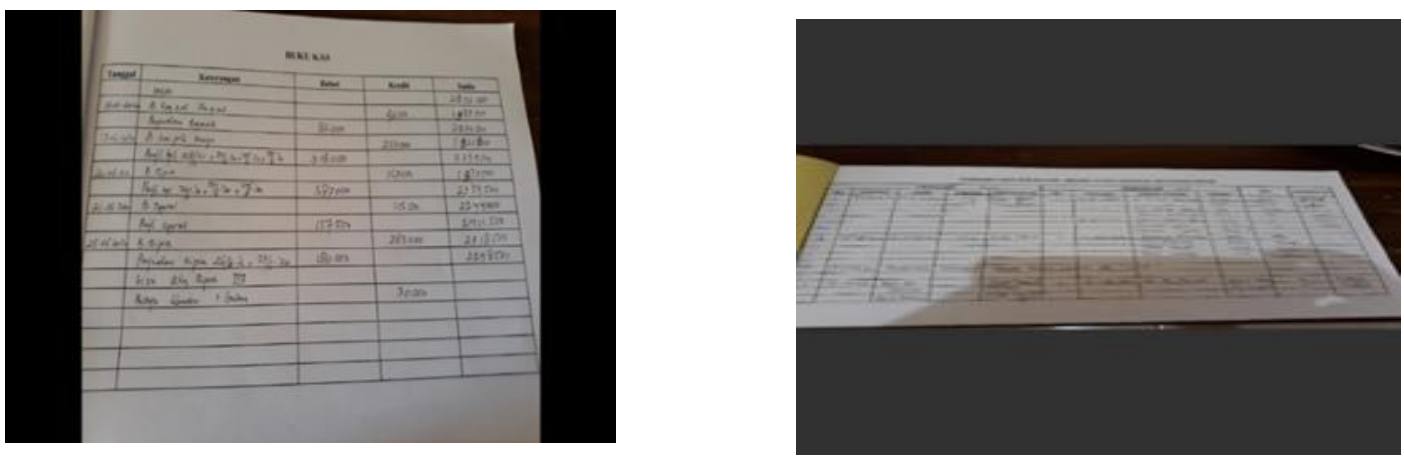

Gambar 18. Buku kas dan buku produksi dan penjualan

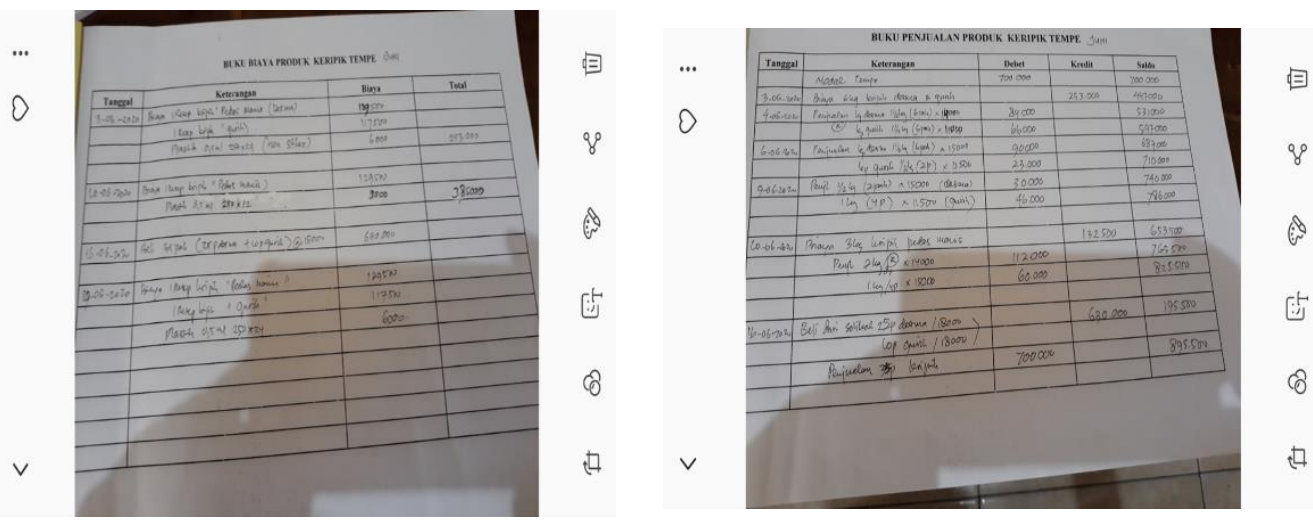

Gambar 19. Buku biaya dan buku penjualan

\section{Simpulan}

1. UKM tempe :

a. Sudah terjadi alih teknologi dari cara tradisional ke cara modern dalam proses pengelupasan kulit kedelai.

b. Sudah memiliki kemasan produk yang dilengkapi dengan merek dan logo.

c. Sudah memiliki buku administrasi keuangan .

d. UKM makanan kecil.

a. Sudah memiliki PIRT. 
b. Sudah memiliki kemasan yang dilengkapi dengan merek, logo dan label.

c. Sudah memiliki media promosi melalui offline yaitu berupa papan nama, dan mempunyai media online berupa wa bisnis, facebook, dan Instagram.

d. Sudah memiliki buku administrasi keuangan

\section{Ucapan Terima Kasih}

Penulis menyampaikan terima kasih kepada:

1. Lembaga Penelitian, Publikasi dan Pengabdian Masyarakat Universitas Muhammadiyah Yogyakarta yang telah memberikan dukungan dana.

2. Pimpinan Cabang Aisyiyah Godean sebagai mitra.

\section{Daftar Pustaka}

Kotler,P.\& K.L.Keller.2013. Manajemen Pemasaran, Edisi13 Jilid 1. Jakarta. Erlangga.

Setiaji, Bamadhita. R. 2019. Kalau Mau Menurunkan Berat Badan, Lebih Baik Makan Tahu Atau Tempe?.https://hellosehat.com/hidup-sehat/nutrisi/tempe-dan-tahu-menurunkanberat-badan/ (diakses 30 Desember 2019).

Utama.D.M. 2019. Penguatan Aspek Manajemen Produksi Dan Kualitas Tempe Pada UKM Tempe. JURNAL PENGABDIAN DAN PEMBERDAYAAN MASYARAKAT ISSN: 25498347 (Online), ISNN: 2579-9126 (Print) Volume 3 No. 1 Maret 2019. Hal.133-140.

Utami, Novia.W. 2020. Keuangan Bisnis : Cara Mudah Membuat Laporan Keuangan UKM Sederhana. Jurnal entrepreneur. https://www.jurnal.id/id/blog/cara-mudah-membuatlaporan-keuangan-sederhana-bagi-ukm/ (diakses 6 Agustus 2020)

“___. Majelis Ekonomi dan Ketenagakerjaan. 2019. http://www.aisyiyah.or.id/id/page/majelisekonomi-dan-ketenagakerjaan.html. (diakses 30 Desember 2019).

“__ ”. Pentingnya Logo Produk Pada Kemasan Untuk Memenangkan Pangsa Pasar. http://desainlogodesign.com/pentingnya-logo-pada-kemasan-produk-dalammemenangkan-pangsa-pasar (diakses 11 Juli 2020) 